\title{
Office Construction in Singapore and Hong Kong: Testing Real Option Implications
}

\author{
Yuming Fu • Maarten Jennen
}

Published online: 18 September 2008

(C) The Author(s) 2008. This article is published with open access at Springerlink.com

\begin{abstract}
We advance the real-option-based empirical analysis of commercial real estate investment in three respects. First, we test several real option implications for real estate construction that have not been examined in the commercial real estate investment literature. In particular and in line with the predictions of real option models, we show that the effects of real interest rate and the expected demand growth on hurdle rent become more negative when the market volatility is greater. Second, we use a cointegrating vector of office employment and office stock to provide a better control of the demand for new construction than traditional indicators based on real estate prices and vacancy rates. Third, whereas the existing studies focus on the U.S. commercial real estate markets, we study two major office markets in Asia, namely Singapore and Hong Kong. We rely on the local stock market in the two city states to derive forward-looking measures of office demand growth expectations.
\end{abstract}

Keywords Office $\cdot$ Construction $\cdot$ Real options $\cdot$ Asia

JEL Classification $\mathrm{D} 81 \cdot \mathrm{G} 31 \cdot \mathrm{L} 74 \cdot \mathrm{R} 33$

\section{Introduction}

Real option theories of irreversible investment decisions (Abel 1983; Dixit and Pindyck 1994) have advanced the empirical literature of real estate investment analysis by improving the prediction of the timing of new construction. Traditional

\section{$\mathrm{Y} . \mathrm{Fu}$}

Institute of Real Estate Studies and Department of Real Estate, National University of Singapore,

4 Architecture Drive, Singapore 117566, Singapore

e-mail: rstfuym@nus.edu.sg

M. Jennen ( $($ )

Finance Department, Rotterdam School of Management, Erasmus University, Room T09-29,

Burg. Oudlaan 50, 3062 PA Rotterdam, The Netherlands

e-mail: mjennen@rsm.nl 
analysis of real estate investment decisions focus mostly on the response of new construction to demand shocks. Studies of commercial office investment, for example, predict construction by lagged growth in office employment and lagged rents (Hekman 1985), by lagged vacancy rates (Rosen 1984) and by lagged office stock relative to office employment (Wheaton 1987; Wheaton et al. 1997). More recent studies allow construction decisions to be influenced also by the cost of capital and volatility as suggested by the real option theories. Sivitanidou and Sivitanides (2000), for example, study office construction in the 15 largest U.S. metropolitan office markets from 1982 to 1998. Their findings show that construction decreases with the cost of capital and the volatility of the demand growth. Holland et al. (2000) report similar findings in a study of the aggregate construction of four categories of commercial real estate in the U.S. from 1972 to 1992.

The extant real-option-based empirical studies of real estate investment are inadequate in a number of respects. First, they leave several important real option implications untested. In particular, Capozza and Li $(1994,2002)$ show that volatility not only delays irreversible investments but also influences the way the investment timing decision is affected by real interest rates and expected rental income growth. Capozza and Li (2001) is the only empirical study that examines the influence of volatility on the way construction responds to interest rate changes but fails to take adequate control of demand shocks in a cross sectional study of residential markets. In the present paper, we seek to examine how volatility affects the impact of interest rate changes and expected demand growth on construction in commercial office markets.

Second, the extant studies provide inadequate control of the demand for new construction. Sivitanidou and Sivitanides (2000), for example, use the office rents relative to construction costs and office vacancy rates to account for the demand for new construction. However, the vacancy rate always converges to a normal vacancy rate as rents adjust to clear the market regardless of the gap between the building stock and its equilibrium level; hence the vacancy rate is a good indicator for price adjustment but a poor indicator for new construction demand. Furthermore, office rents and the construction costs are not necessarily cointegrated, since the difference between the two (in real terms) reflects the real land rent, which is typically nonstationary. Including this nonstationary regressor in the analysis leads to a misspecification of the construction model. Holland et al. (2000) overcome this problem of nonstationary regressors by differencing the construction quantity on the left-hand side of their regression equations and all the explanatory variables on the right-hand side. However, in so doing they eliminate much useful information on disequilibrium gaps contained in the price levels and, not surprisingly, find construction to respond hardly to the price changes. We propose a more satisfactory measure of the demand for new construction based on a stable long-run equilibrium relationship between the office stock and the office employment in a city. When combined, the office stock and office employment form a cointegrating vector, whose variation over time indicates the supply gap to be offset by new construction.

Third, the extant studies usually apply a myopic approach and construct the measures of expected demand growth and volatility based on past growth rates. Holland et al. (2000) represent an exception in that they use a forward-looking 
implied volatility measure derived from commercial real estate debt prices. Reliable prediction of building activities based on real option models requires forwardlooking measures of demand growth expectations. The present paper derives such a measure from the forward-looking behavior of local asset prices. Specifically, we employ the observations from Singapore and Hong Kong office markets to test the real option models. Both city states are major business centers in Asia and the local stock market indices reflect the demand for local business services and hence provide good signals for the forward-looking local office demand growth. ${ }^{1}$

The remainder of this paper is organized as follows. We summarize the implications of the real option models for real estate construction in "Real Option Rules for Real Estate Investment", which is followed by the discussion of our empirical model and data in "Model Specification and Data". We present our findings in "Empirical Findings" and conclude in "Conclusions".

\section{Real Option Rules for Real Estate Investment}

Real option models prescribe rules for the optimal timing of making irreversible investments. Such rules have important implications for asset prices. Real estate construction is an important class of irreversible investments. Titman (1985) is one of the first studies that examine how uncertainty can affect urban land prices. Capozza and Helsley $(1989,1990)$ examine the implications of the optimal timing of land conversion at urban boundaries for urban land rents and prices. In their model, uncertainty raises the hurdle rent that the urban land rent must exceed at the boundary to trigger optimal conversion, delaying the land conversion and pushing up the urban land rent and price. Capozza and Sick (1994) provide a fuller analysis of the effect of demand growth, volatility and the risk premium on the hurdle rent and hence the price of developed land. Capozza and Li $(1994,2002)$ extend the real option model of urban land conversion by allowing variable capital intensity in land development. Earlier empirical studies often focus on testing the real option implications for asset prices; examples include Capozza and Schwann (1989) and Quigg (1993), who examine the influence of real options on the prices of urban land and commercial properties respectively. Capozza and Li (2001), Sivitanidou and Sivitanides (2000), and Holland et al. (2000) are among the early empirical work focusing directly on the influence of real options on investment behavior in real estate markets; each of these studies, however, focuses on a partial set of the real option implications for real estate investments. Our objective in the present paper is to test a set of real option implications that goes beyond the set of implications tested in extant empirical studies. This section summarizes the full set of real option implications for real estate investments as developed in the analytical work of Capozza and Sick (1994) and Capozza and Li (1994, 2002).

The real option rules for the optimal timing of irreversible real estate investment can be prescribed in terms of a hurdle rent $X^{*}$. The underlying demand for real estate

\footnotetext{
${ }^{1}$ The same may not be true for big countries like US, where the stock market indices would reflect the national office demand growth but local office markets need not be highly correlated with the national office demand (Hekman 1985).
} 
is indicated by rent level $X$, which grows at rate $g$ and a diffusion variance $\sigma^{2}$. The investment or conversion takes place as soon as $X$ reaches $X^{*}$; hence a higher $X^{*}$ implies a longer delay before $X$ reaches the conversion trigger. Conversion takes place at a capital intensity $K^{*}$ on a given land parcel to produce floor area $Q\left(K^{*}\right)$. The choice of optimal $K$ can influence the timing of conversion depending on the elasticity of substitution between capital and land. The hurdle rent $X^{*}$ equals the risk adjusted cost of capital $r+\varphi / 2$ multiplied by the average capital cost of construction $K^{*} / Q\left(K^{*}\right)$, as shown in Eq. (1): ${ }^{2}$

$$
X^{*}=\left(r+\frac{\varphi}{2}\right) \frac{K^{*}}{Q\left(K^{*}\right)}
$$

where $r$ is the real interest rate and $\varphi=-\left(g-\lambda-\frac{\sigma^{2}}{2}\right)+\sqrt{\left(g-\lambda-\frac{\sigma^{2}}{2}\right)^{2}+2 \sigma^{2} r}$ is the risk adjustment, which increases with the variance $\sigma^{2}\left(\varphi \geq 0 ; \varphi=0\right.$ when $\left.\sigma^{2}=0\right)$ and interest rate $r$ but decreases with the expected demand growth net of a risk premium, $g-\lambda . \lambda$ is the risk premium associated with the systematic risk of the investment project. Equation (1) is a generalization of the Jorgensonian rule to invest when the cash flow equals the user cost of capital (Jorgenson 1963). The optimal capital intensity $K^{*}$ is chosen such that the marginal revenue of $K, Q^{\prime}\left(K^{*}\right) \cdot X^{*}$, equals the interest rate net of the risk-adjusted growth rate, $r-(g-\lambda)$. The average cost of construction increases with the capital intensity as the marginal product of capital diminishes. When construction is a CES function of $K$ (holding land area fixed) such that $Q(K)=\left[a+(1-a) \cdot K^{(\pi-1) / \pi}\right]^{\pi /(\pi-1)}$, with the elasticity of substitution $\pi \geq 0$, the average cost of construction is given by ${ }^{3}$

$$
\frac{K^{*}}{Q\left(K^{*}\right)}=\left(\frac{1-a}{1-\sigma^{2} / \varphi}\right)^{\pi /(1-\pi)}
$$

where $\sigma^{2} / \varphi$ varies from $g / r<1$ to 1 as $\sigma^{2}$ increases from 0 to $\infty$. Capozza and Li (2002) assume $\pi<1$, so that $K^{*}$ and the average construction cost at which the conversion takes place increase with volatility $\sigma^{2}$ and the risk-adjusted growth rate $g$ $-\lambda$, but decreases with $r$. Table 1 summarizes the comparative statics for hurdle rent $X^{*}$, which forms the hypotheses for the empirical analysis in the present study.

\section{Certainty Case}

Under certainty $\sigma^{2}=0$ and $\varphi=0$, the growth rate $g$ does not affect $X^{*}$ when the cost of construction is fixed. When capital is substitutable for land $(\pi>0)$, a higher $g$ raises $X^{*}$ as the land conversion will take place at a higher capital intensity $K^{*}$. A higher interest rate $r$ increases $X^{*}$ by raising the cost of capital; but when $\pi$ is high, a higher $r$ can decrease $X^{*}$ by reducing $K^{*}$.

\footnotetext{
${ }^{2}$ This is Equation (21) in Capozza and $\mathrm{Li}$ (2002).

${ }^{3}$ See Equation (27) in Capozza and Li (2002).
} 
Table 1 Real option implications for real estate investment decision

\begin{tabular}{|c|c|c|c|c|c|}
\hline \multirow[b]{2}{*}{ Variable } & & & \multicolumn{3}{|l|}{$\pi$} \\
\hline & & & 0 & Low & High \\
\hline \multirow[t]{3}{*}{ Panel a } & \multirow[t]{3}{*}{$g$} & $\sigma^{2}=0$ & 0 & + & + \\
\hline & & Low $\sigma^{2}$ & - & + & + \\
\hline & & High $\sigma^{2}$ & - & - & + \\
\hline \multirow[t]{3}{*}{ Panel b } & \multirow[t]{3}{*}{$r$} & $\sigma^{2}=0$ & + & + & - \\
\hline & & Low $\sigma^{2}$ & + & + & - \\
\hline & & High $\sigma^{2}$ & + & - & - \\
\hline \multirow[t]{2}{*}{ Panel c } & \multirow[t]{2}{*}{$\lambda$} & Low $\sigma^{2}$ & + & - & - \\
\hline & & $\operatorname{High} \sigma^{2}$ & + & + & - \\
\hline Panel d & $\sigma^{2}$ & & + & + & + \\
\hline
\end{tabular}

This Table summarizes the relation between the hurdle rent $X^{*}$ for new construction and four key variables affecting the real option value. Each sign indicates the direction in which the hurdle rent will change when the value of the variable increases, given the level of volatility $\left(\sigma^{2}\right)$ and elasticity of substitution between capital and land $(\pi)$. Panel $a$ shows the effect of the expected growth rate $(g)$ on the hurdle rent. Panel $b$ shows the effect of the real interest rate $(r)$. Panels $c$ and Panel $d$ show the effect of the risk premium $(\lambda)$ and volatility $\left(\sigma^{2}\right)$ respectively

\section{Uncertainty Case}

A higher volatility or total risk $\sigma^{2}$ always increases $X^{*}$ and hence delays construction and increases the capital intensity $K^{*}$ at which the land is developed. Uncertainty makes the effect of $g$ on $X^{*}$ more negative, as a higher $g$ reduces the risk adjustment $\varphi$. Note that the risk premium $\lambda$ always offsets $g$ and hence has an opposite effect on $X^{*}$ as $g$ does. The effect of interest rate $r$ on $X^{*}$ also depends on the volatility. Although a higher $r$ always increases the risk-adjusted cost of capital $r+\varphi / 2$, it reduces $K^{*}$ and the average cost of construction, with a stronger impact on $K^{*}$ when the volatility is higher.

\section{Model Specification and Data}

\section{Model Specification}

Following the literature, we postulate that new construction responds to demand indicators, the cost of capital, and variables embedded in real option theory. As explained in "Real Option Rules for Real Estate Investment", the last two factors are fully summarized by the hurdle rent $X^{*}$. Table 1 spells out how the hurdle rent varies by the real interest rate $r$, expected demand growth $g$, risk premium $\lambda$, volatility $\sigma^{2}$ and the elasticity of substitution $\pi$, as predicted by the real option models. A higher $X^{*}$ means that a greater gap between the demand and the available office stock (hence a higher $X$ ) is required in order to motivate new construction. Table 1 thus forms the hypotheses for testing the real option implications for office construction.

Let $G$ denote the gap between the long-run equilibrium office stock and the presently available office stock $O S . G$ is decreasing in $O S$. The percentage change in $O S$ between period $t$ and $t-1$ is denoted by $\Delta_{t} \ln (O S)$, where $\Delta_{t}$ denotes difference 
between period $t$ and $t-1 . \Delta_{t} \ln (\mathrm{O} S)$ represents net new construction. Thus our basic model for new construction can be written as:

$$
\Delta_{t} \ln (O S)=\alpha_{1}\left(G_{t-1}-X_{t-1}^{*}\right),
$$

where $\alpha_{1}>0$ indicates the speed at which new construction responds to the equilibrium gap in stock and $X^{*}$ represents the hurdle gap (without loss of generality we assume the hurdle gap to equal hurdle rent). Variables that raise hurdle rent $X^{*}$ reduce new construction.

Extant studies employ three types of indicators to measure the gap $G$; they are (1) real estate prices or rents relative to construction costs, (2) vacancy rates, and (3) occupancy demand to available stock, where the occupancy demand equals total employment in the office-use sector multiplied by the space demand per employee that decreases with office rents. The first measure would result in a nonstationary $G$, as the difference between the rent and the construction cost is the land rent, which is likely to be nonstationary over time. Equation (3) would be misspecified if the stationary $\Delta_{t} \ln (O S)$ is to be regressed on a nonstationary $G$. The second measure reflects more the adjustment in rents required to clear the space market than the new construction required to restore the long-run equilibrium level of stock. The third measure suffers the similar problem as the second, as rents will always adjust to equate the occupancy demand with whatever amount of stock available in the market.

We propose to measure $G$ with a cointegration vector between the office stock $O S$ and office employment $O E$. Both $O S$ and $O E$ are endogenous variables but they will adjust so that

$$
G=\theta \cdot \ln (O E)-\ln (O S)
$$

is a cointegration vector; in other words, $G$ as defined by Eq. (4) is stationary in the long run. The elasticity parameter $\theta$ indicates a long-run equilibrating relationship between $O E$ and $O S: O S$ must grow $\theta$ percent in order to accommodate each percentage growth in $O E$ or $O E$ can only grow $1 / \theta$ of whatever percentage growth in $O S$ that takes place. We expect $\theta$ to be less than unity due to improving efficiency in office space use over time. The sources of the efficiency improvement would include the introduction of more flexible office concepts where desk space is used more efficiently, the increase in digitalization and virtual meeting rooms which demand less space and a general tendency of companies to review their space consumption more effectively.

We specify the hurdle rent $X^{*}$ as a linear function of the variables listed in Table 1 . In addition, we include the interactions between volatility $\sigma^{2}$ and the interest rate $r$ and growth $g$ to test how the effects of these two variables depend on the volatility. Thus:

$$
X^{*}=\beta_{0}+\beta_{1} \cdot \sigma+\beta_{2} \cdot r+\beta_{3} \cdot r \cdot \sigma^{2}+\beta_{4} \cdot g+\beta_{5} \cdot g \cdot \sigma^{2}+\beta_{6} \cdot \lambda+\beta_{7} \cdot \lambda_{n},
$$

where $\lambda_{n}$ is a forward-looking measure of expected change in $\lambda$, to be referred to as risk-premium news, to be explained shortly.

At this point we need to be specific about the timing of the variables. The change in the stock $\Delta_{t} \ln (O S)$ is a consequence of investment decisions made several years in advance due to the construction lag. We find a lag of 3 years best fit our data and seems most plausible as land acquisition, planning and construction of high-rise 
office towers in both city states would require substantial time (Sivitanidou and Sivitanides (2000) find a delivery time for office construction between 3.2 and 3.6 years in the U.S.). Thus on an annual basis, we assume $\Delta_{t} \ln (O S)$ in year $t$ to be influenced by the determinants of $X^{*}$ observed three years in advance at the end of year $t-4$. We further assume that at the end of $t-4$ the investors can project the office stock $O S_{t-1}$ based on the stock $O S_{t-4}$ and the building project commencement information. The investors can also project employment at $t-3, O E_{t-3}$.

Combining Eqs. (3), (4) and (5), adding lagged adjustments, and according to the timing assumptions discussed above, we have the following empirical model of office construction:

$$
\begin{aligned}
\Delta_{t} \ln (O S) & =\alpha_{1}\left[\theta \cdot \ln \left(O E_{t-3}\right)-\ln \left(O S_{t-1}\right)-\left(\beta_{0}+\beta_{1} \cdot \sigma_{t-4}+\beta_{2} \cdot r_{t-4}\right.\right. \\
& \left.\left.+\beta_{3} \cdot r_{t-4} \cdot \sigma_{t-4}^{2}+\beta_{4} \cdot g_{t-4}+\beta_{6} \cdot g_{t-4} \cdot \sigma_{t-4}^{2}+\beta_{7} \cdot \lambda_{t-4}+\beta_{8} \cdot \lambda_{n, t-4}\right)\right] \\
& +\alpha_{2} \Delta_{t-1} \ln (O S)+\alpha_{3} \Delta_{t-2} \ln (O E)+\varepsilon_{t}
\end{aligned}
$$

where $\varepsilon_{t}$ is a random residual error. According to Table 1 , we expect that volatility $\sigma$ increases $X^{*}\left(\beta_{1}>0\right)$ and hence slows construction $\Delta_{t} \ln (O S)$. We also expect $\sigma^{2}$ to reduce the positive interest rate effect on $X^{*}\left(\beta_{3}<0\right)$ and to strengthen the negative effect of growth expectation $g$ on $X^{*}\left(\beta_{6}<0\right)$. The sign of $\beta_{2}$ and $\beta_{4}$ will depend on the elasticity of substitution between capital and land; $\beta_{2}\left(\beta_{4}\right)$ would be positive (negative) when the elasticity of substitution $\pi$ is low and negative (positive) when $\pi$ is high. We have no direct measure of $\pi$; however, we will examine whether $\beta_{4}$ is more positive in the earlier part of our sample period when the capital intensity of office construction is relatively lower and the marginal product of capital may be higher. We expect that $\beta_{7}$ has the opposite sign of $\beta_{4}$ in line with relations in Table 1 .

The sign of $\beta_{8}$ is not a priori certain as the extant real option models assume a constant risk premium. We speculate that an anticipated rise in risk premium in the future will lower the current hurdle rent $\left(\beta_{8}<0\right)$, as the value of the option to wait is reduced due to anticipated higher cost of capital in the future.

\section{Data and Variable Construction}

We apply Eq. (6) to examine office construction in Singapore and Hong Kong. The office markets in both city states experienced tremendous growth since the beginning of 1980s; Appendix 1 provides a brief overview of the economic development in the two markets. For Singapore we have semi-annual observations (we denote observations in the first semi-annual period as S1 and second half as S2) from 1980 to 2006 and for Hong Kong, annual observations from 1978 to 2006 (plus projected office stock in 2007). The variables and their sample statistics are presented in Table 2. The majority of the variables we use in our analysis are available from DataStream. These variables are described below.

\section{Office Stock (OS)}

$O S$ represents the total existing floor area of private office space at the end of each observation period. The historic series have been developed by the Urban 


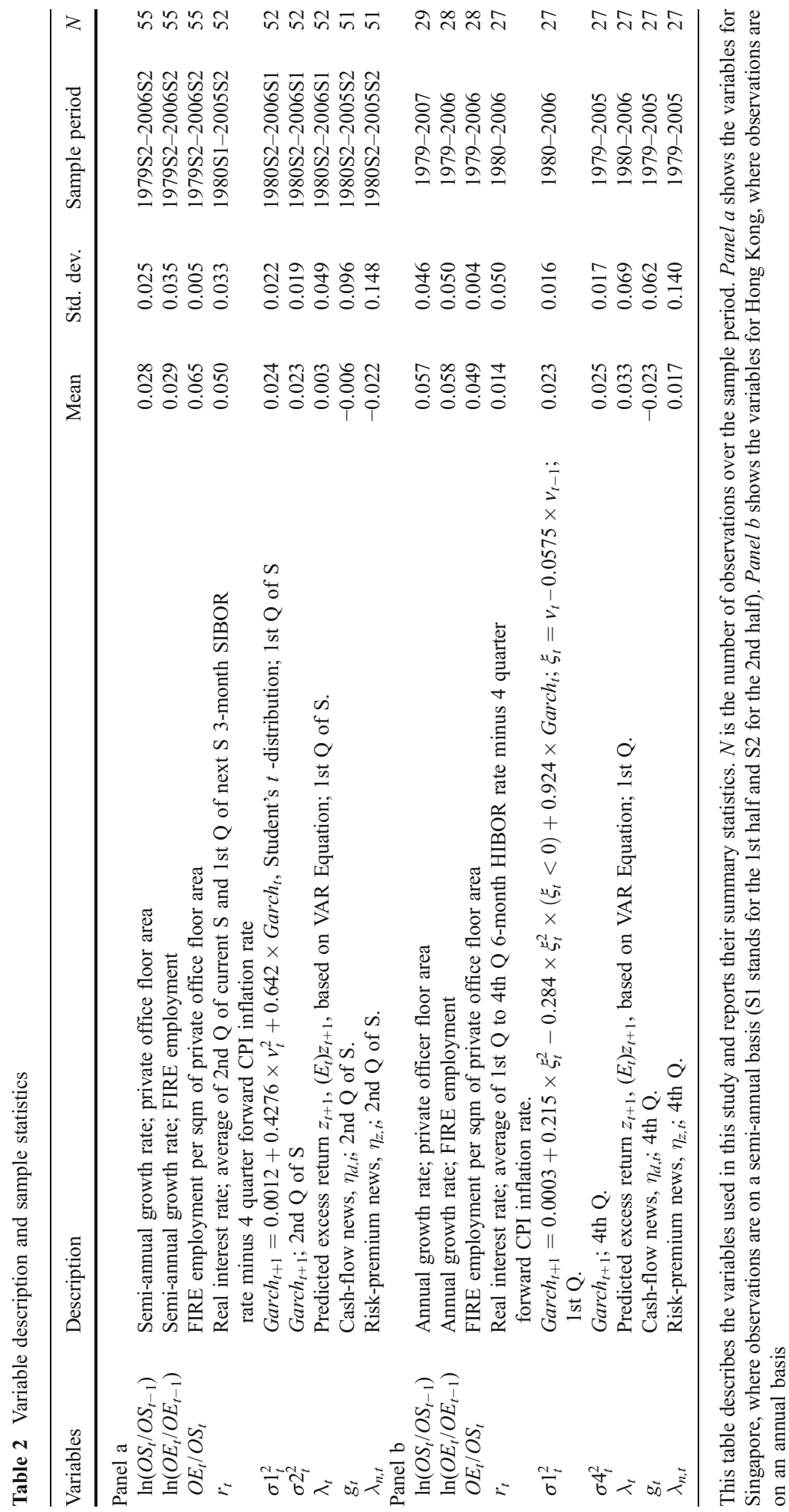


Redevelopment Authority (Singapore) and the Buildings Department (Hong Kong). Given the large scale of some office buildings in major cities, office completions are often lumpy. We adjusted the 1986 OS in Hong Kong to allow for partial completion of a major office development completed in 1987. We did the same for Singapore for 1993 S1 office stock. The office stock grew on average by $2.8 \%$ per semi annual period in Singapore, with a standard deviation of $2.5 \%$; in Hong Kong it grew by $5.7 \%$ per year, with a standard deviation of $4.6 \%$.

\section{Office Employment (OE)}

Office employment is represented by the number of employees in finance, insurance and real estate (FIRE) industries. Employment in FIRE is often used to measure the demand for office space in extant office market studies (see, e.g., Wheaton 1987). $O E$ grew by $2.9 \%$ on average on a semi-annual basis in Singapore, with a standard deviation of $3.5 \%$; in Hong Kong it grew by $5.8 \%$ per year, with a standard deviation of 5.0\%. The FIRE employment grew to 363,000 in Singapore in 2006 and to 491,500 in Hong Kong.

It is interesting to note that the average annual FIRE employment growth is almost the same in both city states. In both cities, the office stock growth is lower than the FIRE employment growth. Also interesting to note is that the demand shocks are more volatile than the supply adjustment, as the standard deviation of the FIRE employment growth is larger than that of the office stock growth.

\section{Real Interest Rate (r)}

In Singapore we use 3-month interbank offered rate (SIBOR) to measure the market interest rate. The Singapore Monetary Authority (MAS) publishes SIBOR rate since 1988. We use UK 3-month interbank offered rate to extend SIBOR rate back to 1980 (the two series have a correlation coefficient of 0.99 between 1988 and 2006). The real interest rate $r$ is computed as the average SIBOR of the 2nd quarter of the current semi-annual period and the 1 st quarter of the next semi-annual period minus the 4 quarter forward CPI inflation rate. For Hong Kong, $r$ is computed as the 4 quarter average 6-month HIBOR rate starting 1 st quarter of the year minus the 4 quarter forward CPI inflation rate. The real interest rate averaged 5.0\% per annum in Singapore and $1.4 \%$ in Hong Kong, although the rate is more volatile in Hong Kong. The lower but more volatile real interest rate in Hong Kong is to a large extent due to the currency board system, which pegs Hong Kong dollar to US dollar. The currency board system constrained Hong Kong's monetary adjustment to local inflation rate; the negative real interest rates experienced in Hong Kong during the mid 1990s were consequences of such monetary constraints.

\section{Stock-market-based Forward-looking Variables}

We take advantage of the active stock markets in the two city states to construct several forward-looking variables for this study, including (1) volatility or total risk, (2) risk premium for systematic risk, (3) demand growth expectations, and (4) risk premium expectations. We do so using the log-linear present-value accounting 
framework of Campbell and Shiller (1988a, b). In this framework, an innovation in the stock-market excess return is accounted for by news about future cash flow growth, future risk premium (expected excess returns), and future interest rates. These news components can be estimated using a VAR model. We follow Campbell (1991) and use a VAR model of three variables, namely stock-market excess return, stock-market dividend yield, and money market rate, to estimate the innovation in the excess return and its constituent news components. Appendix 2 describes the methodology and the VAR estimates. We use Straits Times Index to represent the Singapore stock market and the Hang Seng Index for Hong Kong. These broad stock market indices would reflect the expectation for the overall local economic growth. We expect the office employment in the two city states, which generates the demand for office space, to be highly correlated with the general economy as these two economies are to a large extent driven by trade and business service export. Finance, trade and property sectors account for a major share of the market capitalization of the Hang Seng Index during our study period, whereas these sectors as well as export manufacturers account for a major share of the market capitalization of the Straits Times Index. ${ }^{4}$ These sectors are the major drivers of office demand growth.

It would be interesting to test whether our results change when an index with only financial firms is used for the analysis but unfortunately such an index is unavailable for the full sample period. However, the Dow Jones Total Market Index (DJTMI) and its financial sub-index are available for Singapore and Hong Kong over the period 1992-2008 and they are highly correlated, indicating that our results would not change much. ${ }^{5}$

Let $z_{t}$ denote the observed excess return of the stock market (total return minus the money market rate), $d_{t}$ the cash flow growth in period $t, E_{t}$ the expectation conditional on information available at time $t$, and $\nu_{t} \equiv\left(E_{t}-E_{t-1}\right) z_{t}$ the innovation in $z_{t}$. The conditional expectations are computed based on the estimated VAR model using quarterly observations. The four stock-market-based variables in Eq. (6) are defined below (see Appendix 2 for a full description):

1. volatility, $\sigma_{t}^{2} \equiv \operatorname{GARCH}(1,1)$ of $\nu_{t}$;

2. risk premium, $\lambda_{t} \equiv\left(E_{t}\right) z_{t+1}$;

3. change in demand growth expectation, or cash flow news, $g_{t}=\eta_{d, t} \equiv$ $\left(E_{t}-E_{t-1}\right) \sum_{j=0}^{\infty} \rho^{j} d_{t+j}$, where $\rho<1$ is a discount factor;

4. change in risk premium expectation, or risk premium news, $\lambda_{n, t}=\eta_{z, t} \equiv$ $\left(E_{t}-E_{t-1}\right) \sum_{j=1}^{\infty} \rho^{j} z_{t+j}$.

\footnotetext{
${ }^{4}$ A potential issue with the proposed methodology is related to the locality of the stock market indices and the relation of the broad stock market indices with office demand. Constituent analysis of the Straits Times index and Hang Seng index shows that over $85 \%$ of the companies listed in the Straits Times at the end of 2006 are based in Singapore while for the Hang Seng the local presence was 53.6\% and changes to over $70 \%$ if the Hong Kong and Shanghai Banking Corporation (HSBC) whose headquarter is officially located in London is taken into account. We also find that nine out of ten companies whose headquarter is not located in Hong Kong are from China whose economy is strongly linked to the economy of Hong Kong. ${ }^{5}$ The correlation between the DJTMI and its financial sub-index is 0.94 for Singapore and 0.96 for Hong Kong over the period 1992-2008. The financial sub-indices have a correlation coefficient of 0.83 and 0.84 , respectively, with the Straits Times index and the Hang Seng index.
} 
A positive $\eta_{d, t}$ means a higher expectation of future demand growth, whereas a positive $\eta_{z, t}$ means a higher expectation of future risk premium. Holland et al. (2000) measure the time varying beta of different real estate sectors as the source of variation in systematic risk. We focus our analysis on the time varying risk premium as the source of variation in systematic risk and assume the market beta for the office property sector to be constant over our study period. ${ }^{6}$

\section{Empirical Findings}

The estimates of Eq. (6) for Singapore are reported in Panel a of Table 3. In Column 1 , the long-run office stock elasticity with respect to office employment $\theta$ is jointly estimated with the determinants of the hurdle rent $X^{*}$. We choose a sample period of 1984S1-2002S 2 to estimate $\theta$, as the office construction was very constrained in the last couple of years of our full sample period (hence the $\theta$ value would be underestimated using the full sample period). We obtain a $\theta$ estimate close to 0.7 . In other words, the office stock in Singapore would grow by about $7 \%$ for each $10 \%$ growth in the office employment. The slower growth in the office stock in the long run relative to the employment growth shows the increase in office space efficiency over time. We find the estimate of $\alpha_{1}$ to be highly significant, indicating that the hurdle rent adjusted office stock gap, $G-X^{*}$, has a significant influence on the new construction. About $24 \%$ of the adjusted gap is closed by new construction each half year.

In column 2, we fix the long-run elasticity $\theta$ at 0.7 and examine the determinants of the hurdle rent $X^{*}$ over the sample period of 1984S1-2005S2. The determinants are generally highly significant and have the expected sign. The volatility, measured by $\left(\sigma 1_{t-6}+\sigma 2_{t-7}\right) / 2$, has a very significant positive effect on $X^{*}$. Real interest rate increases $X^{*}\left(\beta_{2}>0\right)$. As the real option model predicts, we find that the real interest rate effect on $X^{*}$ decreases when the volatility is greater. We find that the growth rate $g$ reduces $X^{*}$, as expected under uncertainty when $\pi$, the elasticity of substitution between capital and land, is low. To examine whether the effect of $g$ may be affected by $\pi$ and the volatility, we interact $g$ with two dummy variables, one selects the earlier part of our sample period (1984S1-1990S2) and other selects the periods when the volatility is greater than the median value. We find that the effect of $g$ is more positive in the earlier period, possibly because the elasticity $\pi$ is higher in the earlier period as the office density in CBD would be much lower then (hence the possibility of building at a higher floor-to-area ratio when the demand increases further). As expected, the negative effect of $g$ on $X^{*}$ is much stronger during periods of relatively higher volatility. This result is consistent with the findings in Capozza and Li (2001). Finally, we find that the current risk premium $\lambda$ increases $X^{*}$ and hence slows new construction but an expected increase in $\lambda$ in the future (a positive risk-premium news $\lambda_{n}>0$ ) lowers current $X^{*}$. In column 3 , we extend the sample period to include the last year in our sample, 2006, when the office market was very

\footnotetext{
${ }^{6}$ Beta on a company level is stable if the company remains in the same industry but could alter as a result of changes in technology, market or capital structure. Our analysis focuses on the beta of a broad industry, i.e. a portfolio of companies, which diversifies the impact of changes in beta on the company level.
} 
Table 3 Office construction response to equilibrium gap

\begin{tabular}{|c|c|c|c|c|c|c|}
\hline \multicolumn{4}{|c|}{ Panel a } & \multicolumn{3}{|c|}{ Panel b } \\
\hline & I & II & III & & I & II \\
\hline$\alpha_{1}$ & $\begin{array}{l}0.240 * * * \\
(5.5)\end{array}$ & $\begin{array}{l}0.238 * * * \\
(7.6)\end{array}$ & $\begin{array}{l}0.199 * * * \\
(4.5)\end{array}$ & $\alpha_{1}$ & $\begin{array}{l}0.293 * * * \\
(3.4)\end{array}$ & $\begin{array}{l}0.277 * * * \\
(5.7)\end{array}$ \\
\hline$\theta$ & $\begin{array}{l}0.693 \text { *** } \\
(16.7)\end{array}$ & 0.7 & 0.7 & $\theta$ & $\begin{array}{l}0.762 * * * \\
(12.9)\end{array}$ & 0.75 \\
\hline$\beta_{1}$ & $\begin{array}{l}1.162 * * * \\
(4.0)\end{array}$ & $\begin{array}{l}1.232 * * * \\
(7.0)\end{array}$ & $\begin{array}{l}1.411 \text { *** } \\
(5.1)\end{array}$ & $\beta_{1}$ & $\begin{array}{l}2.533 \\
(1.1)\end{array}$ & $\begin{array}{l}2.916^{* * * *} \\
(3.1)\end{array}$ \\
\hline$\beta_{2}$ & $\begin{array}{l}4.138 * * * \\
(6.3)\end{array}$ & $\begin{array}{l}4.119 * * * \\
(12.7)\end{array}$ & $\begin{array}{l}3.924 * * * \\
(7.5)\end{array}$ & $\beta_{2}$ & $\begin{array}{l}0.537 \\
(1.2)\end{array}$ & $\begin{array}{l}0.603 * * \\
(2.1)\end{array}$ \\
\hline$\beta_{3}$ & $\begin{array}{l}-0.289 * * * \\
(4.0)\end{array}$ & $\begin{array}{l}-0.317 * * * \\
(6.4)\end{array}$ & $\begin{array}{l}-0.342 * * * \\
(4.3)\end{array}$ & & & \\
\hline$\beta_{4}$ & $\begin{array}{l}-0.193 * \\
(1.9)\end{array}$ & $\begin{array}{l}-0.186^{* *} \\
(2.4)\end{array}$ & $\begin{array}{l}-0.222 * * \\
(2.2)\end{array}$ & $\beta_{4}$ & $\begin{array}{l}0.782 \\
(1.2)\end{array}$ & $\begin{array}{l}0.878 * * \\
(2.7)\end{array}$ \\
\hline$\beta_{5}$ & $\begin{array}{l}0.360 \\
(1.5)\end{array}$ & $\begin{array}{l}0.649 * * \\
(2.7)\end{array}$ & $\begin{array}{l}0.606 * * \\
(2.1)\end{array}$ & & & \\
\hline$\beta_{6}$ & $\begin{array}{l}-0.303 \\
(1.2)\end{array}$ & $\begin{array}{l}-0.612 * * \\
(2.4)\end{array}$ & $\begin{array}{l}-0.558^{*} \\
(1.8)\end{array}$ & $\beta_{6}$ & $\begin{array}{c}-0.291 \\
(1.6)\end{array}$ & $\begin{array}{l}-0.320 * * * \\
(3.4)\end{array}$ \\
\hline$\beta_{7}$ & $\begin{array}{l}0.648 * * \\
(2.1)\end{array}$ & $\begin{array}{l}0.772 * * * \\
(3.1)\end{array}$ & $\begin{array}{l}1.160 * * * \\
(2.7)\end{array}$ & $\beta_{7}$ & $\begin{array}{l}1.112 \\
(1.2)\end{array}$ & $\begin{array}{l}1.232 * * \\
(2.5)\end{array}$ \\
\hline$\beta_{8}$ & $\begin{array}{l}-0.233 * * * \\
(2.8)\end{array}$ & $\begin{array}{l}-0.284 * * * \\
(3.8)\end{array}$ & $\begin{array}{l}-0.315^{* * *} \\
(3.2)\end{array}$ & $\beta_{8}$ & $\begin{array}{l}-0.329 \\
(1.1)\end{array}$ & $\begin{array}{l}-0.360 * \\
(1.8)\end{array}$ \\
\hline$\alpha_{2}$ & $\begin{array}{l}0.209 \\
(1.4)\end{array}$ & $\begin{array}{l}0.349 * * \\
(2.7)\end{array}$ & $\begin{array}{l}0.358 * * \\
(2.5)\end{array}$ & & & \\
\hline$C$ & $\begin{array}{l}2.079 * * * \\
(6.7)\end{array}$ & $\begin{array}{l}2.031 * * * \\
(7.7)\end{array}$ & $\begin{array}{l}1.708 * * * \\
(4.6)\end{array}$ & $C$ & $\begin{array}{l}1.857 * * * \\
(5.0)\end{array}$ & $\begin{array}{l}1.804 * * * \\
(5.9)\end{array}$ \\
\hline$R^{2}$ & 0.67 & 0.64 & 0.58 & $R^{2}$ & 0.82 & 0.82 \\
\hline D.W. & 2.3 & 2.14 & 1.9 & D.W. & 1.96 & 1.96 \\
\hline$N$ & 38 & 44 & 46 & $N$ & 24 & 24 \\
\hline
\end{tabular}

This table reports the coefficient estimates of the response in office construction to the equilibrium gap in office stock $G$ and the hurdle rent $X^{*}$. The dependent variable is $\Delta_{t} \ln (O S) \equiv \ln \left(O S_{t} / O S_{t-1}\right)$. The regression equation is $\Delta_{t} \ln (O S)=\alpha_{1}\left[G-X^{*}\right]+\alpha_{2} \cdot \Delta_{t-1} \ln (O S)+\varepsilon_{t}$. Panel a reports the estimates for Singapore, where $G=\theta \cdot \ln \left(O E_{t-5}\right)-\ln \left(O S_{t-1}\right)$, with $t$ being a semi-annual period, and $X^{*}=\beta 1 \cdot\left(\sigma 1_{t-6}+\sigma 2_{t-7}\right) / 2+\beta 2 \cdot r_{t-7}+\beta_{3} \cdot\left(r_{t-7} \cdot \sigma 2_{t-7}^{2} \cdot 100\right)+\beta_{4} \cdot g_{t-7}+\beta_{5} \cdot g_{t-7} \cdot($ Year $<1991)+$ $\beta_{6} \cdot g_{t-7} \cdot\left(\sigma 2_{t-7}^{2}>=0.0165\right)+\beta_{7} \cdot \lambda_{t-6}+\beta_{8} \cdot \lambda_{n, t-7}+\alpha_{2} \cdot \Delta_{t-1} \ln (O S)+C$. Column I shows the regression for sample period $1984 \mathrm{~S} 1$ to $2002 \mathrm{~S} 2$. Column II and III show the results for periods $1984 \mathrm{~S} 1$ to 2005S2 and $1984 \mathrm{~S} 1$ to $2006 \mathrm{~S} 2$, respectively, with the value of $\theta$ fixed at 0.7 . Panel $b$ reports the estimates for Hong Kong, where $G=\theta \cdot \ln \left(O E_{t-3}\right)-\ln \left(O S_{t-1}\right)$, with $t$ being an annual period, and $X^{*}=$ $\beta 1 \cdot\left(\sigma 1_{t-4}^{2}+\sigma 4_{t-5}^{2}\right) / 2+\beta 2 \cdot r_{t-4}+\beta_{4} \cdot g_{t-5}+\beta_{6} \cdot\left(g_{t-5} \cdot \sigma 2_{t-7}^{2} \cdot 100\right)+\beta_{7} \cdot \lambda_{t-4}+\beta_{8} \cdot \lambda_{n, t-5}+C$. The sample period for both Column I and II are from 1984 to 2007, with the value of $\theta$. fixed at 0.75 in Column II. $t$-statistics are in parentheses and are based on Newey-West HAC Standard Errors \& Covariance (lag truncation=3 for Singapore and 2 for Hong Kong). ${ }^{* * *}$ denote statistical significance at $1 \%$ level, $* *$ at $5 \%$ level, and $*$ at $10 \%$ level

tight. The results remain unchanged but the $R$ squared and the $t$ statistics are generally smaller.

Panel $a$ in Fig. 1 shows the trends in the equilibrium gap in office stock $G$ and in the volatility $\sigma 1_{t-6}+\sigma 2_{t-7}$ and the real interest rate in Singapore. The decreasing $G$ from the early 1980s to the early 1990s appears consistent with the generally decreasing market volatility and the real interest rate during the period. The gap was rising in the late 1990s and early 2000s, reflecting the increased volatility during the period as the economy was affected by several shocks, including the Asian Financial 
Fig. 1 This figure shows time trends in volatility and the real interest rates, both on the left hand axis (lhs), and the equilibrium gap $G$ in office stock, on the right hand side axis (rhs). Panel $a$ shows the figure for Singapore on a semi-annual basis over the period 1982S1-2006S2. Here we calculate the equilibrium gap in office stock $G$ as $0.7 \cdot \ln \left(O E_{t+1}\right)-\ln \left(O S_{t+5}\right)$. Panel $b$ shows time trends for Hong Kong on annual basis over the period 1982-2006, where $G=0.75 \cdot \ln \left(O E_{t+1}\right)-$ $\ln \left(O S_{t+3}\right)$. The lead period for $G$ is chosen according to the construction lag

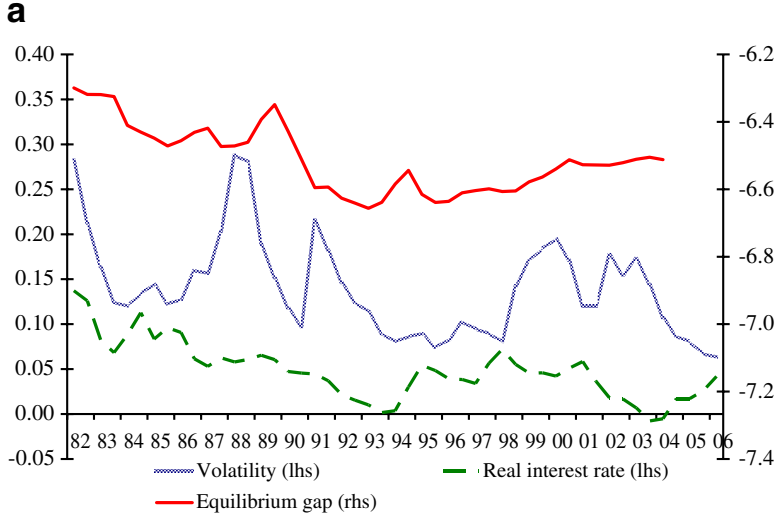

b

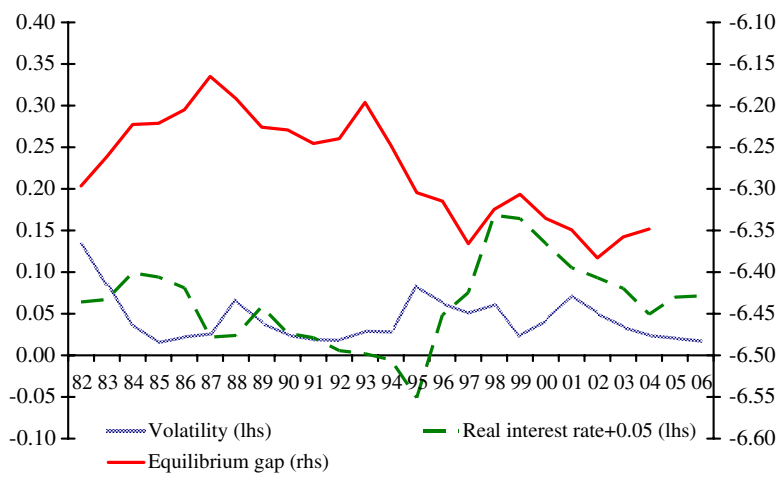

Crisis of 1997-1998, the dotcom bubble burst, and the 2002-2003 SARS epidemic. Panel $a$ in Fig. 2 shows the trends in risk premium, cash flow news and risk premium news.

The estimates of Eq. (6) for Hong Kong are shown in Panel $b$ of Table 3. They are similar to those for Singapore, except that, with much fewer observations at the annual frequency, we cannot include as many variables on the right-hand side of the equation. In column 1 , we have a $\theta$ estimate of 0.76 . The higher elasticity of office stock with respect to office employment growth in Hong Kong may be due to a more restrictive definition of the office employment used in Hong Kong or due to a less intensive space-use technology. In column 2, we fix $\theta$ at 0.75 and examine the determinants of the hurdle rent $X^{*}$. We find the volatility and the real interest rate to increase the hurdle rent, as expected. We find a positive effect of the income growth $g$ on $X^{*}$, perhaps reflecting a higher $\pi$ in Hong Kong due to the generally more generous plot ratio limits for commercial buildings in Hong Kong. Again, as predicted by the real option theories, we find the effect of $g$ on $X^{*}$ to be more negative when the volatility is greater. We find the current risk premium $\lambda$ to increase $X^{*}$ but the expectation for higher future risk premium $\lambda_{n}$ to decrease $X^{*}$, although the latter effect is only marginally significant. Panel b in Figs. 1 and 2 show the trends in the office employment to office stock gap, market volatility, real interest rates, risk premium and the news variables in Hong Kong. 
Fig. 2 Trends in cash flow news, risk premium news and risk premium. Panel $a$ shows cash flow news and risk premium news on the left hand side axis (lhs) and the market risk premium on the right axis (rhs) for Singapore over the period 1982S1-2006S2. Panel b shows the same information for Hong Kong on an annual basis
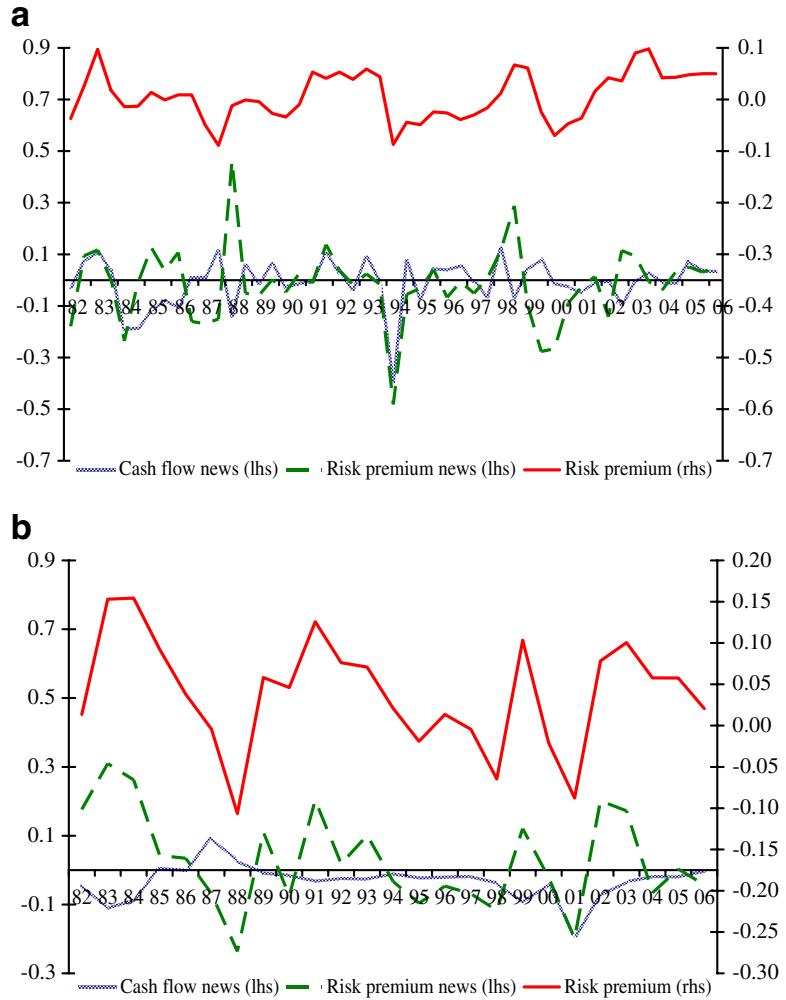

We double check the long-run equilibrium relationship between the office employment and the office stock by examining the covariation between the gap $G^{\prime}=\theta \cdot \ln \left(O E_{t}\right)-\ln \left(O S_{t-1}\right)$ and the real office rent index (we assume that the rental demand in period $t-1$ reflects the office employment in period $t$ ). We regress the log of real rental index $R I$ on log of office employment, $G^{\prime}$, and vacancy rate $v r$ :

$$
\ln \left(R I_{t}\right)=c_{0}+c_{1} \cdot \ln \left(O E_{t}\right)+c_{2} \cdot\left(\theta \cdot \ln \left(O E_{t}\right)-\ln \left(O S_{t-1}\right)\right)+c_{3} \cdot v r_{t-1}+\xi_{t},
$$

where the residual error $\xi_{t}$ may follow a first-order autoregressive process. Coefficient $c_{1}$ reflects the long-run elasticity of office supply (a higher elasticity results in a lower $\left.c_{1}\right), c_{2}$ reflects the office market cycles due to the lags in the supply adjustment to demand shocks, and $c_{3}$ reflects the delay in rental adjustment to clear the space market. We expect $c_{1}$ to be positive due imperfectly elastic long-run supply of office space, $c_{2}$ to be positive as rent moves pro-cyclically to demand shocks, and $c_{3}$ negative for rent adjusts to clear the market (where $v r$ converges to the normal vacancy rate). Table 4 reports the estimates of Eq. (7). We find $c_{2}$ and $c_{3}$ to be significant with expected signs in both office markets. We find $c_{1}$ much smaller in Singapore than in Hong Kong; the land supply for commercial office development is arguably more restrictive in Hong Kong than in Singapore. The estimates of $c_{2}$ appear comparable on the annual basis between the two markets. The residual error is more persistent in Singapore on a semi-annual basis than in Hong Kong on an annual basis, as expected. Overall, the $\theta$ values for Singapore and Hong Kong 
Table 4 Estimates of long-run office rent and the equilibrium gap in office stock

\begin{tabular}{lcc}
\hline & Singapore & Hong Kong \\
\hline$c_{0}$ & $5.554^{*}$ & $6.461^{* * *}$ \\
& $(1.8)$ & $(7.2)$ \\
$c_{1}$ & 0.050 & $0.274^{*}$ \\
& $(0.3)$ & $(2.1)$ \\
$c_{2}$ & $0.860^{* *}$ & $1.556^{* * *}$ \\
& $(2.1)$ & $(5.4)$ \\
$c_{3}$ & $-2.034^{* * *}$ & $-3.005^{* * *}$ \\
& $(2.9)$ & $(2.8)$ \\
$c_{4}$ & $0.849^{* * *}$ & $0.292^{* *}$ \\
& $(13.4)$ & $(2.4)$ \\
$R^{2}$ & 0.91 & 0.86 \\
D.W. & 1.35 & 1.90 \\
$N$ & 39 & 26 \\
\hline
\end{tabular}

This Table reports the regression estimates of the long-run trend in office rent. The dependent variable is $\ln$ $\left(R I_{t}\right)$, where $R I$ is the real office rent index for central area private office in Singapore and grade A private office in Hong Kong. The regression equation is $\ln \left(R I_{t}\right)=c_{0}+c_{1} \cdot \ln \left(O E_{t}\right)+c_{2} \cdot\left(\theta \cdot \ln \left(O E_{t}\right)-\right.$ $\left.\ln \left(O S_{t-1}\right)\right)+c_{3} \cdot\left(\right.$ Vacancy rate $\left._{t-1}\right)+c_{4} \cdot A R(1)+\varepsilon_{t}$, where $\theta \cdot$ has a fixed value of 0.7 for Singapore and 0.75 for Hong Kong. The sample periods are 1987S2-2006S2 and 1981-2006, respectively, for Singapore and Hong Kong. $t$-statistics are in parentheses and are based on Newey-West HAC Standard Errors \& Covariance (lag truncation $=3$ for Singapore and 2 for Hong Kong). ${ }^{* * *}$ denote statistical significance at $1 \%$ level, ${ }^{* *}$ at $5 \%$ level, and $*$ at $10 \%$ level

appear to be a good characterization of the long-run equilibrium relationship between the office stock and the FIRE office employment in these two markets. Figure 3 shows the office market cycles and trends in the two cites.

\section{Conclusions}

We have shown that the real option theories of land conversion (Capozza and Li 1994, 2002) are well capable at predicting the new office construction observed in the two leading Asian business and financial centers, namely Singapore and Hong Kong. We show that investors respond not only to the gap in the office stock relative to its equilibrium level but also to the changes in the hurdle rent over time due to changes in the market volatility, real interest rates, and the expectations about future office demand growth. The most interesting finding is that the volatility not only directly raises the hurdle rent and hence delays new construction but also influences how investment decisions respond to the real interest rate and the growth expectations. We find that the effect of the interest rate and the growth expectation on the hurdle rent become more negative when the volatility is greater, as predicted by the real option models. Few extant empirical studies examine how the effect of the real interest rate and the growth expectation interact with the demand uncertainty. The two city states, Singapore and Hong Kong, offer observations that allow us to examine these important implications of the real option model for real estate investment. Both cities experienced strong growth in the office space demand and significant fluctuations both in demand growth and in real interest rate. Moreover, the availability of the local stock market indexes enables us to construct a more 
Fig. 3 Panel a shows $\ln$ (real office rent $)=\log ($ rent index $/$ $\mathrm{CPI}$ ), and $\ln$ (real office price index $)=\log ($ office price index/ $\mathrm{CPI}$ ), on the left hand axis (lhs); long run supply $=0.05 \cdot \log$ (FIRE employment 1000 )-7; and the equilibrium gap $=0.7 \cdot \ln$ (FIRE employment $\cdot 1000)-\ln$ (office space ${ }_{t-1}$ ), on the right axis (rhs), for Singapore over the period 1982S1-2006S2. Panel $b$ shows the same information for Hong Kong on an annual basis where long run supply equals $0.27 \cdot \ln ($ FIRE employment $)-9.5$ and the equilibrium gap $0.75 \cdot \ln$ (FIRE employment)- $\ln$ (office space $_{t-1}$ )

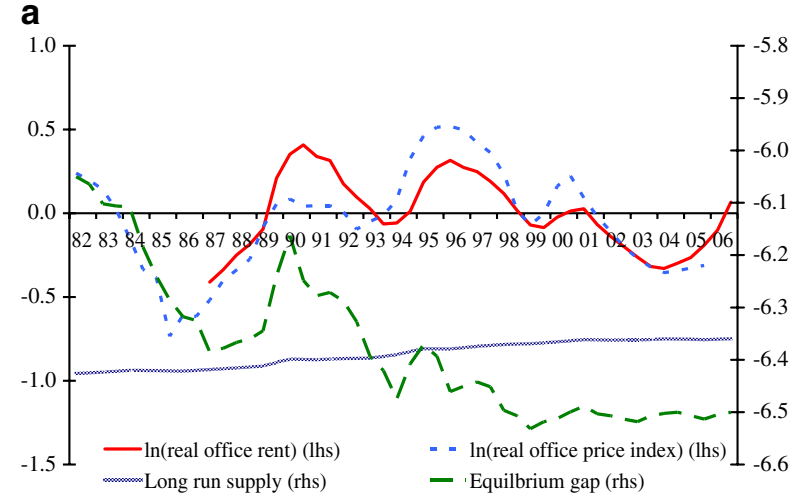

b

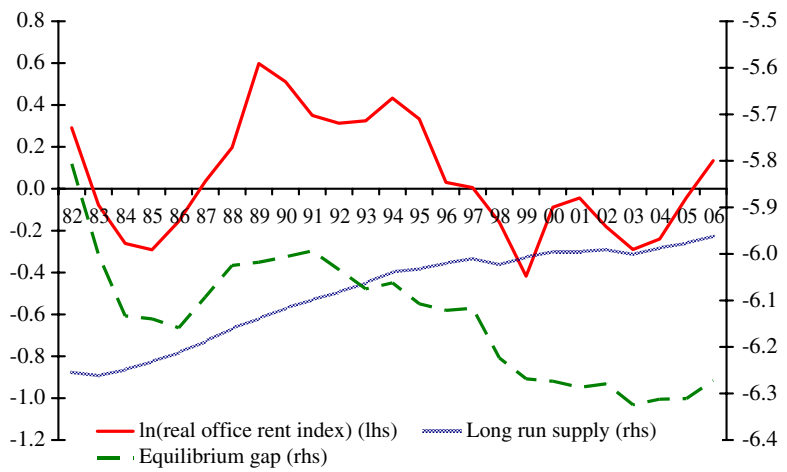

reliable forward-looking measure of the expected demand growth, which is crucial for testing the implications of the real option model.

Our findings have important policy implications. Kling and McCue (1987) find that the decline in interest rates explains the overbuilding in U.S. office markets in the early 1980s. Our findings show that monetary policies designed to cool down real estate investment (by raising real interest rates) could be ineffective and may even produce opposite effects when the demand volatility is high. Furthermore, strong demand growth needs not necessarily accelerate new construction; we find that investors in Hong Kong and Singapore often delayed the new construction when the expectation about the future demand growth rose, consistent with the prediction of the real option model when capital and land are substitutes. Capping the plot ratio could be one way to discourage the delay in new construction when the expected demand growth is strong.

Our findings also suggest a useful direction to extend the real option models of irreversible investment. Extant real option models generally assume a constant risk premium. We show that anticipated changes in the risk premium can influence the timing of irreversible investments. In particular, our finding suggests that the current hurdle rent decreases when the future risk premium is expected to increase, a result yet to be corroborated by analytical modeling. 
Acknowledgements The authors would like to thank Richard Buttimer and other participants in the 2007 The Maastricht-Cambridge-MIT (MCM) Real Estate Finance and Investment Symposium in Cambridge, MA, for their helpful feedback. Furthermore we would like to thank our referee and the editors of the JREFE Special Issue David Geltner and Piet Eichholtz for their comments. Of course, any remaining errors are ours.

Open Access This article is distributed under the terms of the Creative Commons Attribution Noncommercial License which permits any noncommercial use, distribution, and reproduction in any medium, provided the original author(s) and source are credited.

\section{Appendix 1: The Background of the Two Office Markets}

Singapore and Hong Kong are two leading international business and finance centers in Asia. In 2004, 61\% of the world's 100 top banks we present in Singapore while this figure was $63 \%$ for Hong Kong. Singapore is ranked 4th in global foreign exchange and OTC derivatives trading in 2004 and Hong Kong 7th. In 2005, Hong Kong has the 2nd largest stock market capitalization in Asia; Singapore is the 8th. At the end of 2006, Hong Kong has close to 10 million square meters of private office space; Singapore has over 5 million square meters.

Both city states lack natural resources within their small, densely populated geographic areas. They share a common beginning as British trading ports in SouthEast Asia in the 19th century. Both Singapore and Hong Kong underwent considerable economic growth between 1980 and 2005. During this period the population size increased by $80 \%$ in Singapore and $35 \%$ in Hong Kong, whereas real GDP increased by $560 \%$ and $270 \%$ respectively. Both economies have been transformed from a manufacturing export base to important international business service centers since the 1980s. Office employment and the total office market size quadrupled over the period in both cities. Despite the strong growth in the economy and the demand for office space, both economies went through major episodes of volatility during our study period, including the handover of Hong Kong to China by the British government in 1997, the Asia financial crisis in 1997-1998, and the SARS epidemic during 2002-2003. These periods of high volatility provide opportunities for testing the influence of real options on office construction.

Both city states earned their economic success by pursuing free trade and free market policies and rank in the top three economies in terms of global competitiveness. Both governments play a strong role in the supply of new developable land in their cities. ${ }^{7}$ New sites for commercial development are typically granted to private developers under long-term leasehold with specific land-use conditions such as the mix of use and maximum plot ratio. Building construction is required to commence within a certain period of time (typically a few years) upon the grant of the lease. Existing sites can be redeveloped upon successful application for modification of lease conditions. The commercial property development is largely market driven and land supply policies are generally guided by the objective of accommodating market demand. Land supply is generally constrained by the infrastructure projects and, in the case of Hong Kong, by the Sino-British agreement in effect between 1984 and 1997.

\footnotetext{
${ }^{7}$ Ching and Fu (2003) discuss the land market institutions in Hong Kong.
} 


\section{Appendix 2: Stock-market Based Forward-looking Variables}

Investors' expectations about future economic conditions are often capitalized in asset prices. The asset market where prices are most informative of the current economic news is perhaps the stock market. In this paper we make use of the stock prices to back out the market expectations. In particular, we employ the log-linear present-value equation proposed by Campbell and Shiller (1988a, b) to decompose innovations in market excess returns into news about future cash-flow growth, future risk premium (expected excess returns), and future money market rates.

Let $z_{t+1}$ denote the log return of the stock market between time $t$ and $t+1$ in excess of the money market rate $m_{t+1} ; d_{t+1}$ the growth in cash flow between $t$ and $t+$ $1 ; \rho<1$ the long-run discount factor; and $E_{t}$ expectation conditional on the information available at time $t$. An innovation is defined as the change in the expectation between time $t$ and $t+1$ upon the new information arriving at $t+1$. Thus the innovation in the excess return $z_{t+1}$ is defined as $v_{t+1} \equiv\left(E_{t+1}-E_{t}\right) z_{t+1}=$ $z_{t+1}-E_{t} z_{t+1}$, i.e. the realized excess return at $t+1$ minus its expected value based on information available at time $t$. Following Campbell (1991), the decomposition of $v_{t+1}$ can be expressed as:

$$
\begin{aligned}
v_{t+1} & =\left(E_{t+1}-E_{t}\right)\left\{\sum_{j=0}^{\infty} \rho^{j} d_{t+1+j}-\sum_{j=1}^{\infty} \rho^{j} z_{t+1+j}-\sum_{j=0}^{\infty} \rho^{j} m_{t+1+j}\right\} \\
& \equiv \eta_{d, t+1}-\eta_{z, t+1}-\eta_{m, t+1}
\end{aligned}
$$

where $\eta_{d}, \eta_{z}$, and $\eta_{m}$ represent each of the summation in the first line of Eq. (8) and denote respectively the cash-flow growth news, the risk-premium news, and the money-market-rate news. We use the term "news" to refer to changes in expectations due to new information. Equation (8) states that a positive innovation in the excess return, $\nu_{t+1}$, must reflect at least one of the following events: an increased expectation about future cash flow growth, a reduced expectation about future risk premium (expected excess return), or a reduced expectation about future money market rate.

The market news $\eta_{d}, \eta_{z}$, and $\eta_{m}$ can be estimated using a VAR model based on the stock market excess return $z_{t}, \log$ dividend yield $y_{t}$, and the money market rate $m_{t}$. Let vector $\mathbf{w}_{t} \equiv\left[z_{t}, y_{t}, m_{t}\right]^{\prime}$. The VAR model can be written (assuming $\mathbf{w}$ is demeaned) as

$$
\mathbf{w}_{t+1}=\mathbf{A} \cdot \mathbf{w}_{t}+\boldsymbol{\mu}_{t+1},
$$

where $\mu_{\mathrm{t}+1}$ is a vector of residuals. The estimates of the VAR coefficients $\mathbf{A}$ for Singapore and Hong Kong are summarized in Table 5.

Let $\mathbf{e} 1$ be an index vector such that $\mathbf{e} 1^{\prime} \cdot \mathbf{w}_{t}=z_{t}$. Similarly, $\mathbf{e} 3$ is an index vector such that $\mathbf{e} 3^{\prime} \cdot \mathbf{w}_{t}=r_{t}$. Campbell and Shiller (1988a, b) show that, by the recursive property of the VAR equation, the news components can be computed as:

$$
\begin{aligned}
\eta_{z, t+1} & =\mathbf{e} 1^{\prime}(1-\rho \mathbf{A})^{-1} \mathbf{A} \cdot \boldsymbol{\mu}_{t+1}, \\
\eta_{m, t+1} & =\mathbf{e} 3^{\prime}(1-\rho \mathbf{A})^{-1} \boldsymbol{\mu}_{t+1} \\
\eta_{d, t+1} & =v_{t+1}+\eta_{z, t+1}+\eta_{m, t+1}
\end{aligned}
$$


Table 5 Estimates of VAR coefficients

\begin{tabular}{|c|c|c|c|c|c|c|}
\hline Dependent variable & $z_{t}$ & $y_{t}$ & $m_{t}$ & $R^{2}$ & Mean & St dev \\
\hline \multicolumn{7}{|l|}{ Panel a } \\
\hline$z_{t+1}$ & $\begin{array}{l}0.042 \\
(0.4)\end{array}$ & $\begin{array}{l}0.189 * * * \\
(3.3)\end{array}$ & $\begin{array}{l}-2.187 \\
(1.5)\end{array}$ & 0.125 & 0.006 & 0.137 \\
\hline$y_{t+1}$ & $\begin{array}{c}-0.077 \\
(0.7)\end{array}$ & $\begin{array}{l}0.759 * * * \\
(11.0)\end{array}$ & $\begin{array}{l}1.656 \\
(1.0)\end{array}$ & 0.591 & -3.754 & 0.23 \\
\hline$m_{t+1}$ & $\begin{array}{l}0.005 * * * \\
(2.7)\end{array}$ & $\begin{array}{l}-0.002 * * \\
(2.2)\end{array}$ & $\begin{array}{l}0.961 * * * \\
(35.2)\end{array}$ & 0.926 & 0.016 & 0.009 \\
\hline \multicolumn{7}{|l|}{ Panel b } \\
\hline$z_{t+1}$ & $\begin{array}{c}-0.122 \\
(1.3)\end{array}$ & $\begin{array}{l}0.202 * * * \\
(3.5)\end{array}$ & $\begin{array}{l}-3.983 * * \\
(2.2)\end{array}$ & 0.150 & 0.025 & 0.163 \\
\hline$y_{t+1}$ & $\begin{array}{l}0.077 \\
(0.8)\end{array}$ & $\begin{array}{l}0.788 * * * \\
(13.0)\end{array}$ & $\begin{array}{l}3.532 * \\
(1.9)\end{array}$ & 0.676 & -3.352 & 0.279 \\
\hline$m_{t+1}$ & $\begin{array}{l}0.008 * * * \\
(3.1)\end{array}$ & $\begin{array}{l}0.001 \\
(0.6)\end{array}$ & $\begin{array}{l}0.866 * * * \\
(18.1)\end{array}$ & 0.780 & 0.016 & 0.009 \\
\hline
\end{tabular}

This Table shows the estimates of different VAR coefficients where $z_{t}$ is quarterly stock market excess return, $y_{t}$ is $\log$ quarterly dividend yield, and $m_{t}$ is quarterly money market rate. Panel a shows the results for Singapore and Panel $b$ the results for Hong Kong. *** denote statistical significance at $1 \%$ level, ** at $5 \%$ level, and $*$ at $10 \%$ level

where $v_{t+1}=\mathbf{e} 1^{\prime} \cdot \mu_{t+1}$. We calculate the news components with $\rho=0.99$. For Singapore, $\eta_{z, t+1}=[-0.090,0.815,-13.57] \cdot \mu_{t+1}, \quad \eta_{m, t+1}=[0.080,-0.075,14.57] \cdot \mu_{t+1}$; for Hong Kong, $\eta_{z, t+1}=[-0.091,0.814,-5.47] \cdot \mu_{t+1}, \eta_{m, t+1}=[0.056,0.079,7.42] \cdot \mu_{t+1}$. $\mathrm{Fu}$ and $\mathrm{Ng}$ (2001) apply this methodology to computing the news components for both the property markets and the stock market in Hong Kong. They find positive correlation in the market news between the property markets and the stock market; however, the price adjustment to the news in the property markets is much slower than in the stock market.

We measure the volatility using a GARCH model of the variance in stock return innovations $v_{t+1}^{2}$. For Singapore $v_{t+1}^{2}$ is weakly serially correlated and a GARCH $(1,1)$ model is fitted based on quarterly $v_{t+1}^{2}$. For Hong Kong, $v_{t+1}^{2}$ is not serially correlated and a $\operatorname{GARCH}(1,1)$ is fitted based on $\left(v_{t+1}-0.057 \cdot v_{t}\right)^{2}$ with a threshold order of 1 to allow for asymmetric effect of the market shocks on the persistent volatility. As the sample statistics in Table 2 show, the average values of the volatility measure are remarkably similar in the two cities.

\section{References}

Abel, A. (1983). Optimal investment under uncertainty. American Economic Review, 73(1), 228-233.

Campbell, J. Y. (1991). A variance decomposition for stock returns. Economic Journal, 101, 157-179. doi: $10.2307 / 2233809$.

Campbell, J. Y., \& Shiller, R. J. (1988a). The dividend price ratio and expectations of future dividends and discount factors. Review of Financial Studies, 1(3), 195-228. doi:10.1093/rfs/1.3.195.

Campbell, J. Y., \& Shiller, R. J. (1988b). Stock prices, earnings and expected dividends. Journal of Finance, 47(3), 661-676. doi:10.2307/2328190.

Capozza, D. R., \& Helsley, R. W. (1989). The fundamentals of land prices and urban growth. Journal of Urban Economics, 26(3), 295-306. doi:10.1016/0094-1190(89)90003-X. 
Capozza, D. R., \& Helsley, R. W. (1990). The stochastic city. Journal of Urban Economics, 28(3), 187203. doi:10.1016/0094-1190(90)90050-W.

Capozza, D., \& Li, Y. (1994). The intensity and timing of investment: The case of land. American Economic Review, 84(4), 889-904.

Capozza, D. R., \& Li, Y. (2001). Residential investment and interest rates: An empirical test of land development as a real option. Real Estate Economics, 29(3), 503-519. doi:10.1111/1080-8620.00020.

Capozza, D. R., \& Li, Y. (2002). Optimal land development decisions. Journal of Urban Economics, 51, 503-519. doi:10.1006/juec.2001.2240.

Capozza, D. R., \& Schwann, G. (1989). An asset approach to pricing urban land: Empirical evidence. Real Estate Economics, 17(2), 161-174. doi:10.1111/1540-6229.00481.

Capozza, D. R., \& Sick, G. A. (1994). The risk structure of land markets. Journal of Urban Economics, 35 (3), 297-319. doi:10.1006/juec.1994.1018.

Ching, S., \& Fu, Y. M. (2003). Contestability of the urban land market: An event study of Hong Kong land auctions. Regional Science and Urban Economics, 33, 695-720. doi:10.1016/S0166-0462(03) 00005-X.

Dixit, A. K., \& Pindyck, R. S. (1994). Investment under uncertainty. Princeton: Princeton University Press.

Fu, Y. M., \& Ng, L. K. (2001). Market efficiency and return statistics: Evidence from real estate and stock markets using a present-value approach. Real Estate Economics, 29(2), 37-61. doi:10.1111/10808620.00009 .

Hekman, J. (1985). Rental price adjustment and investment in the office market. Journal of the American Real Estate and Urban Economics Association, 13(1), 33-47.

Holland, S., Ott, S., \& Riddiough, T. (2000). The role of uncertainty in investment: An examination of competing investment models using commercial real estate data. Real Estate Economics, 28(1), 3364. doi:10.1111/1540-6229.00792.

Jorgenson, D. (1963). Capital theory and investment behavior. American Economic Review, 53, 247-259.

Kling, J. L., \& McCue, T. E. (1987). Office building investment and the macroeconomy: Empirical evidence, 1973-1985. Journal of the American Real Estate and Urban Economics Association, 15(3), 234-255. doi:10.1111/1540-6229.00430.

Quigg, L. (1993). Empirical testing of real option-pricing models. Journal of Finance, 48(2), 621-640. doi: $10.2307 / 2328915$.

Rosen, K. T. (1984). Toward a model of the office building sector. Journal of the American Real Estate and Urban Economics Association, 12(3), 261-269. doi:10.1111/1540-6229.00322.

Sivitanidou, R., \& Sivitanides, P. (2000). Does the theory of irreversible investments help explain movements in office-commercial construction. Real Estate Economics, 28(4), 623-661. doi:10.1111/ 1540-6229.00814.

Titman, S. (1985). Urban land prices under uncertainty. American Economic Review, 75(3), 505-514.

Wheaton, W. (1987). The cyclical behavior of the national office market. Journal of the American Real Estate and Urban Economics Association, 15(4), 281-299. doi:10.1111/1540-6229.00433.

Wheaton, W. C., Torto, R. G., \& Evans, P. (1997). The cyclical behavior of the greater London office market. Journal of Real Estate Finance and Economics, 15(1), 77-92. doi:10.1023/ A:1007701422238. 